\title{
The Management Process at the Pretrial Stage under Malaysian Rules of Court 2012
}

\author{
Norman Zakiyy \\ Faculty of Law, National University of Malaysia, 43600 UKM Bangi, Selangor, Malaysia/ \\ Senior Lecturer, Universiti Sains Islam Malaysia \\ Email: zakiyy@usim.edu.my \\ Kamal Halili Hassan \\ Professor, Faculty of Law \\ National University of Malaysia, 43600 UKM Bangi, Selangor, Malaysia \\ Email: k.halili@ukm.edu.my
}

\section{Abstract}

The pre-trial stage requires judicial attention as well as attention from solicitors representing the parties to the action to ensure that cases are managed and disposed within strict deadlines. This study recommends the use of management process activities that are commonly used by business organizations to manage civil cases in the Malaysian civil courts at the pre-trial stage. Therefore, the objectives of this study are; first, to examine whether the provisions under the Rules of Court 2012 are capable of delivering quality service in its role as the fortress of justice and how the understanding of management process can assist in the management and disposal of cases efficiently. The findings indicate that the activities of process management (namely planning, organizing, directing and controlling exercises) can be used as a practical guide for the court managers as well as solicitors acting for the parties to the action to understand the importance of abiding by the provisions of the Rules of Court 2012 so that the management and disposal of cases can be done in an efficient manner. Although this study does not analyze the various process management theories, it is expected that the preliminary findings might enrich present literature relating to the conduct of civil litigation and also provide an insight on possible adoption of a framework to be used as a guide in managing cases under the Rules of Court 2012.

Keywords: Management process, pretrial stage, Rules of Court 2012, Malaysia

\section{Introduction}

Generally, the term 'management process' refers to a combination of activities which involve planning and monitoring the performance of a company from the aspects of business processes. Notably, companies that have obtained the ISO 9001:2000 Quality Management Standards certification process has given plenty of emphasis on their processes and endeavour to increase quality as well as efficiency. In brief, ISO 9000 highlights the importance of managing an organization with the right process, especially in terms of ensuring an effective quality management system apart from improving and meeting customer satisfaction (clause 0.2 of ISO 9001:2000).

Apparently, modern judicial systems generally place great importance of effective management of cases to ensure that cases are processed justly, swiftly and efficiently to meet the public's expectation. For instance, a number of judicial systems depend on the use of the electronic court system (instead of the manual system). The Malaysian civil courts have benefited from the use of technology which comprises of the following systems: Case Management System (CMS); Queue Management System (QMS); and Court Recording Transcription (CRT) (Saman \& Haider, 2012; Hassan \& Mokhtar, 2011). In the administration of justice, however, the court is neither a business entity nor a profitable organization and rarely refers to business principles in managing the loads of cases that are registered daily.Nevertheless, it is expected to improve its service from time to time especially in the era of advancement of technology. It is observed that the effective use of certain 
provisions under the Rules of Court 2012 has not been tested as capable of assisting the parties to the action, their respective solicitors or the court to manage cases effectively. In the light of this circumstance, this study examined whether the management process used in businesses, namely planning, organizing, directing and controlling are principles that are equally applicable in managing cases at the pre-trial stage under the Rules of Court 2012. Therefore, this study is significant in determining the potentials of applying management process principles to manage the pre-trial stage.

Based on the foregoing, the main objective of this study is to examine the relevance of using the principles of process management in managing the pre-trial stage under the Rules of Court 2012. The general objectives of this study are; first, to analyze the related provisions of the Rules of Court 2012 that correspond to the principles of process management; and to understand the importance of management process in the management and disposal of civil cases efficiently.

\section{The Pretrial Stage and its relevance to Process Management}

The day-to-day management process of a company involves the activities of planning, organizing, directing and controlling. However, "management process" is an unfamiliar term in court management and also in the management of cases by legal firms. Although the term is subject to various definitions by scholars, it can be described as an interconnected process that involves "concerted efforts to map, improve and adhere to organizational processes" (Benner \& Tushman, 2007). The term has also been used to describe the various activities that are organized in the making of a product (Wesk, M 2012). According to Griffin and Ebert (2006), business managers usually rely on such activities in their respective organizations. In addition, planning involves 3 key components, namely determining the firm's goals; next the development of a comprehensive strategy for realizing those goals and followed by crafting tactical and operational plans for realizing the strategy. According to the authors, the act of organizing means deciding on the best way to use a business's resources and activities into a coherent structure whilst the act of directing involves the use of power by a manager to direct and motivate employees to meet the firm's objectives; and the act of controlling means the process of monitoring the firm's performance got ensure that the firm is meeting its goals.

In civil litigation, the way a case is managed throughout the litigation track is important in determining whether it is managed efficiently or otherwise. For a case which requires disposal via a trial or is complex in nature, the pre-trial stage is an important stage. In Malaysia, a strict deadline for civil courts has been set by the Malaysian Judiciary. For an ordinary civil case, the disposal time is nine (9) months for the High Court and Sessions' Court, and within six (6) months for the Magistrates' Court. In this connection, the placing of such strict key performance on the court indicated that the management process involved in managing civil litigation under the Rules of Court 2012 must not be taken lightly by all parties concerned - the courts, the solicitors acting for the parties to the action and other stakeholders. To achieve targeted goals (a win or win-win situations), strategies employed in civil litigation must be planned and organized accordingly. And managing the pre-trial stage requires one to achieve a combination of skills and strategies and not purely dependable with the use of the electronic court system alone. Thus, it is essential to draw a link between management process and the pretrial stage.

For the court, cases that enter the court registry must be managed and disposed within certain timelines. On the other hand, to the solicitors, taking up a case means that they must plan during the pre-trial stage and prepare accordingly for trial. This essentially includes the need to be well-prepared during the pre-trial case management, which conduct is governed under Order 34 of the Rules of Court 2012. In this sense, it is quite similar to the conduct of any business that requires careful planning to ensure that the resources are used efficiently and effectively, to achieve specific goals. The close of pleadings is a stage whereby the parties to the action or their respective solicitors are required to observe a set of pre-trial procedures. Under the Rules of Court 2012, these procedures (in chronological order) are case management, mediation, discovery of documents, discovery by interrogatories, inspection and setting down for trial (Abu Baker, 2012). ${ }^{1}$ Failing to act or manage their cases, according to these procedures would end up with possible dismissal of action as evidenced by several court judgments. In Birkett $v$ James ${ }^{2}$ [1977] 2 All ER 801, Lord Diplock held that the plaintiff in that case has failed to act cautiously and had caused inordinate and inexcusable delay and as such has caused serious

${ }^{1}$ Hamid Sultan Bin Abu Baker, Janab's Key to Civil Procedure - COMBINED RULES (The Rules of Court 2012 Annexed), Janab (M) Sdn. Bhd., Malaysia, $5^{\text {th }}$ dn, $2^{\text {nd }}$ Reprint, 2012, $\mathrm{p} 194$.

${ }^{2}$ Birkett v James [1977] 2 All ER 801 [1977] 2 All ER 801 
prejudice to the defendant. Similarly, in Syed Mahdzir bin Syed Abdullah v. Ketua Polis Negara \&Anor. ${ }^{1}$ [1986] 1 MLJ 196.Mohamed Dzaiddin J. (As he then was) held that the plaintiff's action, intentional and contumelious default and the existence of inordinate and inexcusable delay plaintiff or his solicitor had had caused his action to be struck out for want of prosecution). Based on the above discussion, there is a link between process management and the management of cases in terms of deciding on the activities that are important in ensuring the success of management. This study hopes to fill the existing gaps in the civil procedure literature that discuss a little about the relevance of adopting management activities in the management of cases.

\section{Methodology}

Studies in procedural law involve examination of the provisions in statutes, case laws, court procedural rules and court practice directions/circulars. The major sources of data include the provisions of the Rules of Court 2012 and case laws. The methods employed in this study were descriptive and aimed at fact finding. To accomplish this task, the relevant provisions in the Rules of Court 2012 were analyzed to find out what are the activities under the Rules of Court 2012 that resemble the basic idea of activities that take place in the process management of an organization.

\section{Findings and Discussion}

The finding shows that the Rules of Court 2012 contain provisions that promote a robust approach in managing civil cases at the pre-trial stage and in many aspects are quite similar to the approaches used by many business organizations. Although the activities involved in managing cases and business affairs are not necessarily identical, they are interrelated in the sense that both processes provide guidance to organizations to manage their affairs efficiently and orderly.

The study identified relevant provisions of the Rules of Court 2012 that correspond to the principles of process management (namely planning, organizing, directing and controlling exercises) that are commonly referred in managing business organizations. The activities of process management (namely planning, organizing, directing and controlling) may assist the court and the solicitors acting for the parties to the action to understand the importance of abiding by the provisions as set forth under the Rules of Court 2012 to achieve the end of justice in an efficient manner.

\section{a. Planning process}

Quite similar to the process of planning undertaken by business managers, legal firm managers and even lead counsel also spend a great deal of time planning for the success or smooth management of a case. To achieve efficiency in the disposal of cases, the Rules of Court 2012 contain provisions that stipulate the importance of planning for the processes involved once a case is filed and thereupon registered by the court. These processes include the use of modern technology, worker skills and materials (cause papers). Performance quality herein refers to the features of ensuring high-quality monitoring by the court.

The three key components of planning (namely, determining the firm's goals; the development of a comprehensive strategy for realizing those goals and followed by designing tactics and plans for implementing the strategy) are equally relevant to the practice of a legal firm manager. Likewise, a lead counsel on a case is professionally required to ensure that their clients' interests are safeguarded throughout the litigation stages. The main goal of accepting a brief (case) from a client is to ensure the success of his case apart from serving the end of justice. Thus, counsels acting for the plaintiff would start collecting and verifying all facts that were revealed to them by their respective clients. This can be done by perusing every document that may seem to be relevant and any person who may have the relevant information. Specific steps would be reasonably taken which include the following: Sending letter, requesting form information; collecting and reviewing witness statements and any such statement made by potential defendants. With such preparation, commencement of action can be done without much doubt and would allow the exchange of pleadings without encountering much problem.

${ }^{1}$ Syed Mahdzir bin Syed Abdullah v. Ketua Polis Negara \&Anor [1986] 1 MLJ 196. 


\section{i.Planning process for the plaintiff's solicitors}

The Rules of Court 2012 contain provisions that must be abided by both solicitors acting for the parties to the action in their capacity as officers of the court.

\subsubsection{The planning process for the plaintiff's solicitors would include the following:}

1. The Plaintiff's solicitors must plan the process of his client's case carefully in line with the direction under the Rules of Court 2012. They would, firstly, ensure that the writ of summons must be served promptly and within the validity period, namely, 6 months beginning from the date of its issue and a concurrent writ is valid in the first instance for the period of validity of the original writ which is unexpired at the date of issue of the concurrent writ (Rules of Court 2012, Order 6 , rule 7). Equally important, is that the statement of claim must also be served within 14 days after the defendant has entered an appearance (Rules of Court 2012, Order 18, rule 1). In an action where the defendant is not represented, the Plaintiff's solicitors would need to ensure that the defendant's solicitors are served according to two methods, namely via personal service of by prepaid A.R. Registered post upon the extraction of the sealed copy of the court (Rules of Court 2012, Order 10, rule 1). If substituted service is required, then they are required by the Rules of Court 2012 to make an application for substituted service, followed by obtaining the court order before attempting to effect service on the defendant and lastly to file an affidavit confirming the service of the writ of summons via substituted service in Court. 2. Similarly, if substituted service is required, the Plaintiff's solicitors must get leave from the court via filing a notice of application and effect service upon getting order-in-terms of the said application. In furtherance of this, if the defendant fails to enter an Appearance, and no extension of time has been applied for, then Plaintiff's counsel should consider applying for default judgment.

3. In terms of planning a strategy, the Plaintiff's solicitors may also consider applying for summary judgment. This is a summary way recommended under the Rules of Court 2012 (Rules of Court 2012, Order 14). Tactical plans to realize this strategy would involve examining the Defence and determine whether the Defendant has no defense to his case.

4. Similarly, the Plaintiff's solicitors can resort to filing an application for striking out if it is found that the defence is not sound in law. Alternatively, other strategies that can be adopted by the Plaintiff's solicitor are such as filing in relevant applications in situations where the defendant has made any admissions or where it is appropriate to amend the pleadings or to add, substitute or remove any party to the action or to file a Reply if the Defence raises new fact.

\subsubsection{The planning process for the defendant's solicitors would include the following:}

1. In safeguarding the Defendant's interest, enter an appearance within specified timeline by filing the Memorandum of appearance (Rules of Court 2012, Order 12, rules 1 and 2) and on the same date on which the Defendant has entered his appearance, send a copy of the same to the plaintiff by post (if he sues in person) or his solicitors (if the plaintiff sues by way of legal representation) (Rules of Court 2012, Order 12, rule 3(2)).

2. In strategizing a possible defense plan, sent a letter to Plaintiff's solicitors informing that they are in the midst of preparing the Defence. Obtain agreement that Judgment in Default of Defence (JID) will not be entered without reasonable notice.

3. Service of defence on the plaintiff before the expiration of 14 days after the time limited for appearance or after the statement of claim is served on him, whichever is the later (Rules of Court 2012, Order 18, rule 2 (1) and (2)).

4. In realizing the strategy, examine the statement of claim and consider whether it discloses a cause of action. If not, apply for striking out.

5. Apply for summary judgment on counterclaim (Rules of Court 2012, Order 14, rule 5)

6. Determine whether sufficient information disclosed in the statement of claim. If not, request for further and better particulars. 
7. Whether there are scandalous, vexatious, or embarrassing allegations. If exist, apply for striking all or a portion of the statement of claim.

8. Determine whether any admission is made by the plaintiff

9. Determine what evidence is needed to support the plaintiff's allegations

10. Identify any presumption of law that works for or against the defendant.

11. Prepare and file defence within specified timeline.

12. Prepare brief authorities

\subsubsection{The planning process which is applicable for both solicitors acting for plaintiffs and solicitors acting for defendants:}

- $\quad$ Consider the need to file application for further and better particulars to avoid the element of surprise.

- $\quad$ Generally, case management is aimed at preparing the parties to the action for trial apart from disposing cases early. Thus, solicitors acting for both parties to the action should consider the need to adopt suitable alternative dispute resolution procedures (ADR procedures) for managing potentially difficult or protracted litigation. Against this backdrop, it is imperative to consider the importance of certain ADR mechanisms to ensure that cases are disposed within the aforementioned strict deadlines.

- $\quad$ Apart from mediation and arbitration, consider the use of early neutral evaluation, which has the potential of extending it to case planning, especially if mediation is not an appropriate dispute resolution mechanism to be used in a particular case and fails to convince the parties to reach settlement.

\section{a. Quality organization}

There are also provisions in the Rules of Court 2012 that promote the need to organize efficiently to ensure services rendered by the court and the tasks and responsibility of both the solicitors acting for the parties to the action are organized accordingly. This essentially requires the joint effort of all staff on the court as well as solicitors and the parties to the action. The evidences are as follows:

The organization of the courts' business is regulated by the Registry (Rules of Court 2012, Order 60, rule 1). It is divided into several departments and the business of the Registry shall be distributed among the departments according to the direction of the Chief Judge or the Sessions court judge (for the lower courts). The Registry keeps the records or books as prescribed under the Rules of Court 2012 and this includes a Cause Book, an Interlocutory Application Book and a Judgment Book. The Rules of Court 2012 also stipulates that a judge of the high court shall be made available as a vacation judge to ensure the smooth running of the court's business (Rules of Court 2012, Order 61, rule 1).

The filing of a writ of summons (and notice of application) must be done accordingly, namely via electronic-filing or by using the service of a service bureau are done correctly (Rules of Court 2012, Order 63A, rule 7). For electronic filing, the plaintiff's solicitors need to submit legal documents via Electonic Filing System (payment via internet banking). For the registry, the registration clerk would verify the documents and process the documents by stamping, placing a mention date et cetera on the PDF documents. Then, such documents would send to the Senior Assistant Registrar (or the Deputy Registrar) in duty who would sign and digitally place a seal on the PDF documents (Rules of Court 2012, Order 63A, rule 8). The court would then notify the status of filing and case number (Rules of Court 2012, Order 63A, rule 9). Processed, then forward to solicitors with digital seal. The Plaintiff's solicitors will print the court document and serve to the defendant (or his solicitors, if he is legally represented) and later validate service of such document via electronic filing. Thereafter the defendant's solicitors will submit the defence (submit payment via internet banking). The court will then notify them about the status of filing and processed the said document with a digital seal.

Similarly, the filing of affidavits using the electronic filing service can be done electronically or manually (by the deponent himself by signing the original paper affidavit) (Rules of Court 2012, Order 63A, rule 13).

The flow of events in the conduct of civil litigation must be organized according to the Rules of Court 2012 and observed by both solicitors acting for the parties to the action. Examples are aplenty:

Example 1: Obtaining judgement-in-default of appearance. 
After the defendant has failed to file in his appearance, judgment-in-default of appearance will be entered and recorded by the court. However, if the defendant has entered an appearance within the specified timeline by filing the Memorandum of appearance, the court is required under the Rules of Court 2012 to affix an official stamp acknowledging the date on which such documents have been received. (Rules of Court 2012, Order 12, rule 3). Similarly, if defense is not served within specified timelines, judgment in default of defence will be entered and recorded by the court.

Example 2: The determination of when the pleading is deemed closed (Rules of Court 2012, Order 18, rule 20).

At the expiration of 14 days after service of the reply of, if no reply, but only a defence to a counterclaim, after service of the defence to the counterclaim; or if neither a reply nor a defence to a counterclaim is served, at the expiration of 14 days after service of the defence (Rules of Court 2012, Order 18, rule 20 (1)(a) and (b)).

Example 3: Pre-trial preparation and pre-trial case management

After the close of pleadings, pre-trial case management will be fixed by the court (Rules of Court 2012, Order 34, rule 2). At this stage, solicitors acting for the parties to the action make make any interlocutory application (Rules of Court 2012, Order 34, rule 9). For example, any party to the action can file in an application for summary judgment (Rules of Court 2012, Order 14). For example, the plaintiff who has served the statement of claim on the defendant and that the defendant has entered an appearance, the plaintiff may on the ground that the defendant has no defence to a claim, or a particular part of a claim stated in the writ, except as to the amount of damages claimed, apply for summary judgment. At the case management stage, pre-trial preparation will include the carrying out of the following tasks:

i.Check for new case laws (on court procedures and substantive laws relating to the area)

ii.Consider any possible change in the position of the parties (e.g. Based on the pleadings and discovered documents)

iii.Consider what evidence is needed at trial and how evidence will be led

iv.Confirm availability of witnesses

v.Consider notice to admit facts

vi.Disposal of cause on a point of law (Rules of Court 2012, Order 14A)

vii.Production, inspection and preservation or property

viii.Interlocutory injunction (prohibitory, mandatory or Mareva) (Rules of Court 2012, Order 29)

ix.Withdrawal of discontinuance (Rules of Court 2012, Order 21)

x.Consent order

4 Research the law

5 Organization of documents based on originality

6 Discovery and inspection of documents (Rules of Court 2012, Order 24)

7 Experts of parties (Rules of Court 2012, Order 40A)

8 Admissions (Rules of Court 2012, Order 27)

9 Witnesses - list of prospective witnesses

\subsection{Quality direction}

There is need to understand the benefits of abiding by the Rules of Court 2012. To achieve this, training and involvement of all parties concerned must not be discounted for. In this respect, the Judicial and Legal Service Training Institute (ILKAP) is a government agency that has received validation of MS ISO 9001:2008 on 19 Mac 2010 by Llyod's Register Quality Assurance (LRQA) with the mission to improve knowledge, competency and professionalism especially among judicial and legal officers and law enforcers. ILKAP is established to achieve important functions such as the organization of training programmes, seminars and courses. It also conducts research relating to the need of training and impact analysis on the organization and officers from the public services, statutory bodies and local authorities who are in the judicial and legal services and the enforcement of laws. ILKAP may train their judicial officers, especially with regards to the importance of encouraging the parties to the action to reach amicable resolution of disputes via the use of dispute resolution mechanisms, wherever possible and the function of certain court procedures such as court connected Mediation (under the Rules of Court 2012, Order 34, rule 2) and the Notice of Attendance of pre-trial case management (under Rules of Court 2012, Order 34, rule 4).

b.

Quality control 
The Rules of Court 2012 assist the court to monitor the litigation track by enabling the court and even any one of the parties to the action to detect errors in law and facts and make the necessary action as stipulated under the Rules of Court 2012. Evidences are as follows:

i. The filing of actions throughout the litigation process requires the observance of specific rules under the Rules of Court 2012 and the use of specific standardized forms as specified for commencing certain actions. For instance, writ of summons (Form 2A Rules of Court 2012, Order 6, rule 1), application for substituted service application Form 134 under Order 62, r 5) and memorandum of appearance (Form 11 Rules of Court 2012, Order 12, rule 2). However, the Court shall have regard to the interests of justice and not on technical non-compliance with the Rules of Court 2012 (Rules of Court 2012, Order 1A). Thus, any non-compliance should be treated as an irregularity. Furthermore, the court shall not entertain any preliminary objection to non-compliance of rules (Rules of Court 2012, Order 2, rule 3).

ii.The court controls the way pleadings are drafted. For instance, the rule of thumb is that there is a need to plead specifically in certain matters (Rules of Court 2012, Order 18, rule 8). However, there may be a situation when points of law in pleading must be pleaded ( Rules of Court 2012, Order 18, rule 11), the need to plead facts and not evidence (Rules of Court 2012, Order 18, rule 7), (restriction of raising any new ground or claim inconsistent with a previous pleading of his own (Rules of Court 2012, Order 18, rule 10), and the necessary particulars which must be stated in a pleading (Rules of Court 2012, Order 18, rule 12).

iii. However, the Rules of Court 2012 warns that any amendment to pleadings must not be treated lightly. It states that any amendment to a writ after its service on the defendant must be done via ex parte application and must be served on the defendant (Rules of Court 2012, Order 20, rule 1 (2)) amendment of memorandum of appearance must be with leave of the court (Rules of Court 2012, Order 20, rule 2). The court requires that amendment must be done within 14 days upon amendment order, failing which such order shall cease to have effect (Rules of Court 2012, Order 20, rule 9)

iv.Applications must be done with good faith and fair play. For instance, the Rules of Court 2012 prescribe that the court will see that the Plaintiff's application for substituted service is done properly. In this sense, the Plaintiff must show effort to effect service on the defendant within 1 month from the date of the issue of the writ of summons and followed by subsequent efforts thereto to effect service of the same (Rules of Court 2012, Order 6, rule 7 (2A)).

v.The Rules of Court 2012 also controls the withdrawal and discontinuance of action. The plaintiff may withdraw action within 14 days after service of defence on him by serving a notice in Form 32 Rules of Court 2012, Order 6, rule 7(2A) )

vi. The court will ensure that a judgment shall not be entered against a defendant unless the plaintiff produces a certificate of non-appearance in the prescribed court form (Form 12) and an affidavit is filed by or on behalf of the plaintiff proving due service of the writ on the defendant or in the alternative, the plaintiff produces the writ of summons which has been endorsed by the defendant's solicitor with a statement that confirms the acceptance of the writ on behalf of his client (the defendant) (Rules of Court 2012, Order 13, rule 7 (1)).

vii. The court is vested with the discretion to set aside or vary any judgment made by it, if it thinks just to do so (Rules of Court 2012, Order 13, rule 8).

viii.Based on the above explanation, any step taken must be evaluated and reviewed so that the proper or right recourse is sought. The parties to the action or their respective solicitors must comply with any such court order, especially pertaining to case management order, or else face the court's wrath. The Court is vested with the discretion to dismiss the action or strike out the defence or counterclaim or enter judgment or make such other order as deemed fit if any party fails to attend to it accordingly (Rules of Court 2012, Order 34, rule 6).

\section{Implications of the Study}

It is observed that abiding by the Rules of Court 2012 will benefit the solicitors to develop rational advice in order to cater to the needs of their respective clients as to the next logical course of action in the litigation process, namely either to look forward to a settlement plan or proceed to trial.

\section{Conclusion}


The study indicates that the provisions of the Rules of Court 2012 support the use of the management process. A number of provisions of the Rules of Court 2012 support the robust approach needed by solicitors acting for the parties to the action as well as the Malaysian civil court in achieving its initiatives in managing cases efficiently to meet the end of justice. It is axiomatic to note the use of the management process activities are relevant in considering the efficient and systematic management of:

(a) Disposition time for cases

(b) Amicable resolution of disputes, wherever possible (with or without the assistance of a third-party neutral); and

(c) Protection of the rights and interests of each party to the action

\section{Limitations of the Study}

This study has encountered the usual limitations of time and funds commonly faced by a non-funded study. Thus, this study can only be considered as a preliminary study.

\section{Recommendations}

Active case management is an important aspect in civil litigation in Malaysia and even in most countries in other parts of the world. In this regard, it is recommended that the courts and the Malaysian Bar must initiate consciousness among court managers/administrators and solicitors about the effectiveness of using basic activities in the management process in the management of cases. Equally important is that the subject of Civil Procedure for law students should include the topic of management process and relate it to pre-trial case management under the Rules of Court 2012 so that students may visualize and determine what a solicitor would want to achieve in managing a case.

\section{References}

[1] Abu Baker, H.S. B. (2012). Janab's Key to Civil Procedure - COMBINED RULES (The Rules of Court 2012 Annexed), (5th.Ed.), Janab (M) Sdn. Bhd., Malaysia.

[2] Benner, M. J., \& Tushman, M. (2007). Process management, technological innovation, and organizational adaptation. Business Process Transformation, 317-326.

[3] Hassan K.H. \& Mokhtar M.F., The E-court System in Malaysia, A paper presented at the 2011 2nd International Conference on Education and Management Technology. Retrieved from: http://www.ipedr.com/vol13/46T10012.pdf, IPEDR vol.13 (2011) @ (2011) IACSIT Press, Singapore.

[4] Saman W.S.W.\& Haider, A. Electronic Court Records Management: A Case Study, Journal of e-Government Studies and Best Practices. Retrieved from:http://www.ibimapublishing.com/journals/JEGSBP/jegsbp.html, Vol. 2012 (2012), Article ID 925115, DOI: 10.5171/2012.925115

[5] Wesk, M. (2012). Business Process Management: Concepts, Languages and Architects, Springer, Science and Business Media, Retrieved from: https://scholar.google.com/citations?view_op=view_citation\&hl=en\&user=Qc4JtWcAAAAJ\&citation_for_view= Qc4JtWcAAAAJ:Ial1MmNe2tcC

[6] Griffin, R.W., \& R.J. Ebert (2006)., Business, (8th ed.). New Jersey: Prentice Hall, Pearson Education International. 


\section{Reported cases:}

Birkett v James [1977] 2 All ER 801 [1977] 2 All ER 801

Syed Mahdzir bin Syed Abdullah v. Ketua Polis Negara \&Anor [1986] 1 MLJ 196.

\section{Statute/Court Rule}

Rules of Court 2012 (Malaysia) 